\title{
Influence of Age on ortho-Hydroxyphenylacetic Acid Excretion in Phenylketonuria and Its Genetic Variants
}

\author{
Françorse Rey, ${ }^{28]}$ Catherine Pellié, Monique Sivy, Félicienne Blandin-Savoja, \\ JEAN REy, and JeAn FrézaL \\ Unité de Recherches de Génétique Médicale (INSERM), Hôpital des Enfants Malades, Paris, France
}

\section{Extract}

Excretion in urine of $o$-hydroxyphenylacetic acid (o-OH-PAA) was measured quantitatively during a 24-hr period in 43 children ranging from 2 weeks to 12 years of age who were affected by different types of hyperphenylalaninemia (20 typical phenylketonuria (PKU) 7 atypical PKU, and 16 mild forms according to the classification of Auerbach et al.); 28 out of the 33 cases diagnosed at birth in the course of a screening program were examined before reaching 3 months of age. Phenylpyruvic acid (PPA) excretion was estimated at the same time semiquantitatively.

It was found (1) that ferric chloride tests were negative constantly and the daily excretion of $o-\mathrm{OH}-\mathrm{PAA}$ was always inferior to $5 \mu \mathrm{M} / 24 \mathrm{hr}$ in the younger group when the level of phenylalanine in plasma was below $1.5 \mu \mathrm{mol} / \mathrm{ml}$; (2) that 0 -OH-PAA excretion increased significantly as the children got older: $11.0 \pm 3.8$ before 3 months, $16.1 \pm 15.9$ at 6 months, $75.0 \pm 48.5$ at 1 year, and $122.1 \pm 84.7 \mu \mathrm{M} / 24 \mathrm{hr}$ at 2 years of age for levels of phenylalanine in plasma which ranged from 1.5 to $2.1 \mu \mathrm{mol} /$ $\mathrm{ml}$; (3) that the excretion thresholds for o-OH-PAA and PPA reached adult values $(0.4-0.5$ and $0.7-0.9 \mu \mathrm{mol} / \mathrm{ml}$, respectively) only after 2 years.

In 16 cases, using intravenous perfusion of $0.06 \mathrm{~m} \mathrm{~L}$-phenylalanine, we have shown also that the PPA and o-OH-PAA excretion was identical whatever the type of (PKU) or mild forms) insofar as the levels of phenylalanine in plasma reached (1.5$3.0 \mu \mathrm{mol} / \mathrm{ml}$ ) were equal in both types.

\section{Speculation}

This paper presents observations which demonstrate that only a minute amount of 0 -OH-PAA is excreted daily in the urine of both classic PKU and other forms of hyperphenylalaninemia during the first months of life. It is suggested that this very low excretion is caused by a delayed maturation of phenylalanine transaminase; it is further proposed that the different types of hyperphenylalaninemia, with the exception of those caused by a deficiency of the tyrosine-oxidizing system, are all secondary to mutations affecting the phenylalanine hydroxylase system.

\section{Introduction}

Because no simple enzymatic techniques are available, the method used to distinguish between defects af- fecting either phenylalanine hydroxylation or transamination is based on several biochemical criteria and especially on the presence or absence of $o$-OH-PAA 
and PPA in the urine of patients [8, 22]. These metabolites are, of course, normally found in urine with levels of phenylalanine in plasma greater than 0.4 $\mu \mathrm{mol} / \mathrm{ml}(7 \mathrm{mg} / 100 \mathrm{ml})$ for the former and $0.9 \mu \mathrm{mol} /$ $\mathrm{ml}(15 \mathrm{mg} / 100 \mathrm{ml}$ ) for the latter, their catabolism being, below these values, faster than their synthesis $[3,6,16]$. However, the influence of age on their excretion has as yet never been analyzed systematically in children under 2 years of age. This fact prompted us to undertake this study in 28 children affected by classic and so-called "Mediterranean" PKU as well as by mild hyperphenylalaninemia detected at birth by submitting them to oral or intravenous phenylalanine loads. By analyzing the results obtained at different ages and those recorded in older patients (mentally retarded or not), it was found that the transaminase system is not mature until 2 years of age, making it impossible to use the presence or absence of phenylalanine metabolites in urine to determine, at the time of birth, which enzymatic step is being affected.

\section{Methods}

Forty-three children ( 23 boys and 20 girls), who ranged in age from 2 weeks to 12 years, were studied. Thirtythree cases were detected at birth, 17 in our laboratory, and 16 by the Evian Screening Center; the remaining 10 were recognized at older ages, either because of mental retardation or in the course of familial investigations. They were classified, according to the terminology of Auerbach et al. [8], as a function of the level of phenylalanine in their plasma at the time of the diagnosis, as they were fed a diet containing $3 \mathrm{~g}$ protein $/ \mathrm{kg}$ body wt; under these conditions, 20 were considered as affected by typical PKU, 7 by atypical PKU, and 16 by mild hyperphenylalaninemia.

Daily excretion of PPA and $o-\mathrm{OH}-\mathrm{PAA}$ in urine was measured in every case at the time of the initial diagnosis except for three typical and two atypical PKU cases detected at birth in whom $o-\mathrm{OH}-\mathrm{PAA}$ determination was not made until 1 or 2 years of age. The same measures were repeated as hyperphenylalaninemia decreased to normal values after the onset of the treatment in those who were submitted to a restricted diet. They were measured again at the ages of 6 months, 1 year, or 2 years; for this purpose, during a 4- to 6-day period, they were fed a diet containing the equivalent in phenylalanine of $3 \mathrm{~g}$ protein $/ \mathrm{kg}$ body wt. Moreover, the excretion of these metabolites in urine was studied in 16 cases (10 typical or atypical PKU and 6 mild forms) after an intravenous perfusion of $0.06 \mathrm{M} \mathrm{L}$ - phenylalanine $\left(500 \mathrm{ml} / \mathrm{m}^{2}\right.$ in $\left.3 \mathrm{hr}\right)$; the level of phenylalanine in plasma was thus raised to $2.5-3.0 \mu \mathrm{mol} /$ $\mathrm{ml}$; urine samples were collected during the first $6 \mathrm{hr}$ and then every $12 \mathrm{hr}$ until phenylalaninemia was returned to initial values; 0 -OH-PAA excretion was plotted against the logarithmic mean of phenylalanine in plasma for each time interval.

Phenylalanine in plasma was measured at $\mathrm{pH} 4.3$ by column chromatography [24] with a single $0.2 \mathrm{~N} \mathrm{Na}+$ citrate buffer [23] or on microsamples $(10 \mu \mathrm{l})$ by automatic fluorometry [24] according to the technique of Hill et al. [14]. Assay of $o-O H-P A A$ was made quantitatively by the technique of Armstrong et al. [5], modified as follows: descending chromatography was performed in one dimension on Whatman no. 1 filter paper with isopropyl alcohol-aqueous ammonia- $\mathrm{H}_{2} \mathrm{O}$ (20/1/2); diazotized $p$-nitroaniline was sprayed to visualize the phenolic compounds; after elution of the $o$ OH-PAA spot, OD was read at $530 \mathrm{~nm}$. Concentrations of $0.01 \mu \mathrm{M}$ can be detected safely by this method [13]. Excretion of PPA was estimated from trace to very positive levels $(++)$ by ferric chloride tests, $\mathrm{DPNH}^{+}$reactions, and Phenistix; the enol-borate technique was used in a few cases.

\section{Results}

\section{PPA and o-OH-PAA Excretion in Children under 3 Months of Age}

In children under 3 months of age, at the time of the first admission to the metabolic ward, there is practically no excretion of PPA $(<0.5 \mathrm{~mm} /$ liter as controlled by the enol-borate method) as long as the level of phenylalanine in plasma is below $1.5 \mu \mathrm{mol} /$ $\mathrm{ml}$; above this value, ferric chloride tests are always positive (traces or + ) but never ++ , even if phenylalaninemia exceeds $3.0 \mu \mathrm{mol} / \mathrm{ml}$. Whatever the type of hyperphenylalaninemia, $o$-OH-PAA excretion remains very low also $(<5 \mu \mathrm{M} / 24 \mathrm{hr})$ until the level of phenylalanine in plasma exceeds $1.5 \mu \mathrm{mol} / \mathrm{ml}$; it then increases proportionally to the blood level, being, on the average, $10 \mu \mathrm{M}$ for phenylalanine levels ranging from 1.5 to $2.1,15 \mu \mathrm{M}$ from 2.1 to 2.7 , and $20 \mu \mathrm{M} / 24 \mathrm{hr}$ over 2.7 $\mu \mathrm{mol} / \mathrm{ml}$ (Fig. 1). At that age, therefore, with a protein intake of $3-4 \mathrm{~g} / \mathrm{kg}$ body wt, ferric chloride tests and $o$ OH-PAA excretion are positive in typical and atypical PKU only; in mild hyperphenylalaninemia, where, by definition, the level of phenylalanine in plasma is below $1.5 \mu \mathrm{mol} / \mathrm{ml}$ whatever the protein intake, results are always negative (Table I). 


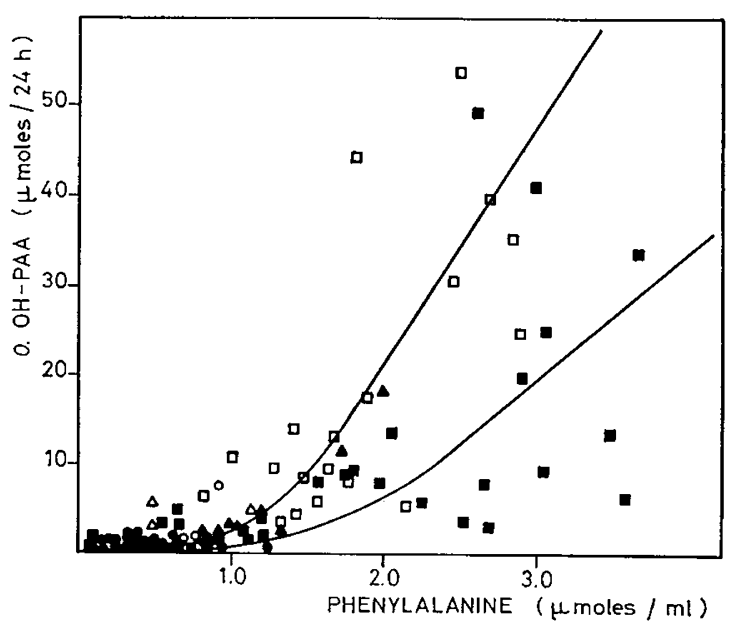

Fig. 1. o-Hydroxyphenylacetic acid $(O . O H-P A A)$ excretion expressed as a function of plasma phenylalanine in typical phenylketonuria $(\boldsymbol{\square}, \square)$, in atypical phenylketonuria $(\boldsymbol{\Delta}, \Delta)$, and in mild hyperphenylalaninemia $(\bullet, 0)$ before they reach 3 months of age $(\boldsymbol{\square}, \boldsymbol{\Delta}, \boldsymbol{e})$ and at 6 months of age $(\square, \Delta, 0)$. - drawn by inspection, represents the mean for each age group.

Variations with Age of PPA and o-OH-PAA Excretion

The concentration of PPA in urine becomes progressively greater as the patients get older; values above $2.5 \mathrm{~mm} /$ liter $(++)$ are observed at 1 year of age for phenylalaninemia exceeding $1.8 \mu \mathrm{mol} / \mathrm{ml}$ and at 2 years of age for phenylalaninemia exceeding $1.2 \mu \mathrm{mol} /$ $\mathrm{ml}$; the threshold for PPA excretion decreases after 2 years of age to 0.7 or $0.8 \mu \mathrm{mol} / \mathrm{ml}$. Excretion of $o-\mathrm{OH}$ PAA increases in the same way; it is significantly higher at 6 months than it is during the neonatal period $(P<0.001)$, higher at 1 year than at 6 months, and higher at 2 years than at 1 (Figs. 1 and 2); the figures obtained in the oldest group for the class interval $(0.4-0.9 \mu \mathrm{mol} / \mathrm{ml})$ are identical with those recorded in the youngest group for the highest plasma levels (Table II).

\section{Comparison between PKU and Mild Forms after Intra- venous Perfusion}

Excretion of PPA increases with age in this condition also; ferric chloride tests are, in fact, always positive after the age of 2 years for the highest plasma levels $(2.4-3.0 \mu \mathrm{mol} / \mathrm{ml})$ in the mild forms as in typical and atypical PKU (pooled in Tables III and IV because of the small number of patients). Taking age into account, $o$-OH-PAA is also similar if not higher in some mild form cases than in PKU.

\section{Discussion}

In spite of some contradictory statements [1, 2], it is now established firmly that the screening for PKU must be done during the first days of life by measurement of phenylalaninemia and not of its primary metabolites in urine i.e., PPA and o-OH-PAA $[10,18]$. Unquestionable observations of typical as well as atypical PKU for which a transient transamination defect had been suspected because of the negativity of the urine tests for several weeks have, in fact, been published $[4,8,15]$. Isolated phenylalanine transaminase deficiencies were also postulated by Auerbach in 1965 [7], and several observations were later attributed to

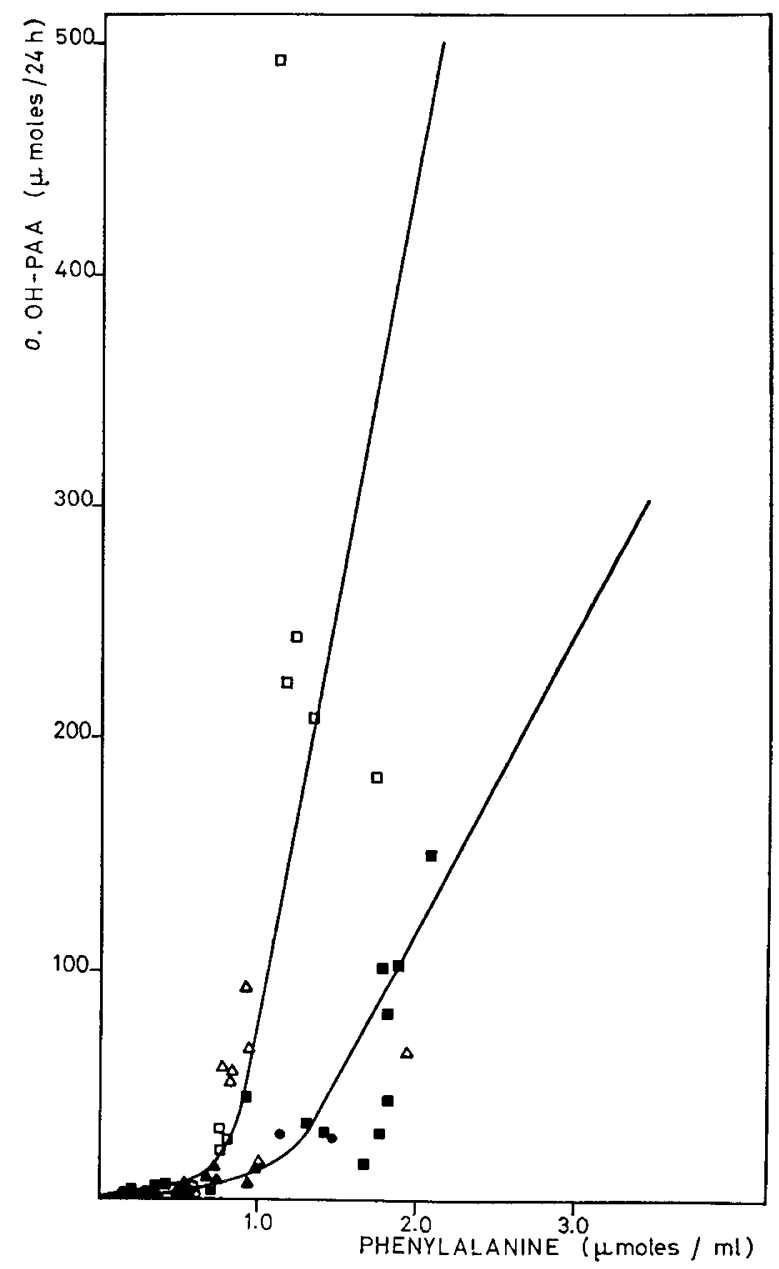

Fig. 2 o-Hydroxyphenylacetic acid (O. OH-PAA) excretion expressed as a function of plasma phenylalanine in typical phenylketonuria $(\boldsymbol{\square}, \square)$, in atypical phenylketonuria $(\boldsymbol{\Lambda}, \Delta)$, and in mild hyperphenylalaninemia $(\bullet, O)$ at 1 year of age $(\boldsymbol{\square}, \mathbf{\Delta}, \bullet)$ and over 2 years of age $(\square, \triangle, O) ;-$, drawn by inspection, represents the mean for each age group. 
this group $[8,22]$, although the enzymatic defect has never been proved directly.

Our results show clearly $(l)$ that despite very high levels of phenylalanine in plasma, minute excretions of PPA and $o$-OH-PAA are the rule during the first weeks of life; (2) that for equal plasma levels, PPA concentration is always higher after 1 year of age than before; (3) that $o$-OH-PAA excretion is, on the aver-

Table I. o-Hydroxyphenylacetic acid in micromolar concentration per $24 \mathrm{hr}$ as function of type of hyperphenylalaninemia and of level of phenylalanine in blood in children with phenylketonuria (PKU) under 3 months of age

\begin{tabular}{|c|c|c|c|c|c|c|c|}
\hline \multirow{2}{*}{ Group } & \multirow{2}{*}{$\begin{array}{l}\text { No. of } \\
\text { patients }\end{array}$} & \multicolumn{6}{|c|}{ Class interval of phenylalanine conc., $\mu \mathrm{M} / \mathrm{ml}$} \\
\hline & & $<0.4$ & $0.4-0.9$ & $0.9-1.5$ & $1.5-2.1$ & $2.1-2.7$ & $>2.7$ \\
\hline $\begin{array}{l}\text { Typical PKU } \\
\text { Range }\end{array}$ & 10 & $0.5 \pm 0.9^{\mathrm{I}}(9)^{2}$ & $\begin{array}{c}2.3 \pm 1.6(5) \\
(0.9-4.9)\end{array}$ & $\begin{array}{c}\text { 26. } \pm 1.1(5) \\
(1.2-3.9)\end{array}$ & $\begin{array}{c}9.5 \pm 2.3(5) \\
(7.8-13.4)\end{array}$ & $\begin{array}{c}13.9 \pm 19.9(5) \\
(2.7-49.3)\end{array}$ & $\begin{array}{c}21.1 \pm 12.8(7) \\
(6.2-41.0)\end{array}$ \\
\hline $\begin{array}{l}\text { Atypical PKU } \\
\text { Range }\end{array}$ & 3 & $0(2)$ & $2.9(1)$ & $\begin{array}{c}3.3 \pm 0.6(5) \\
(2.9-4.3)\end{array}$ & $\begin{array}{c}14.8 \pm 5.0(2) \\
(11.2-18.3)\end{array}$ & & \\
\hline $\begin{array}{l}\text { Mild type } \\
\text { Range }\end{array}$ & 15 & $0.8 \underset{(0-2.3)}{ \pm} 0.7(15)$ & $\begin{array}{c}0.9 \pm 0.6(13) \\
(0-2.0)\end{array}$ & $0.5(2)$ & & & \\
\hline
\end{tabular}

Mean $\pm \mathrm{so}$.

2 Number of observations.

Table II. o-Hydroxyphenylacetic acid in micromolar concentration per $24 \mathrm{hr}$ as function of age and of level of phenylalanine in blood; all types of hyperphenylalaninemia are pooled

\begin{tabular}{|c|c|c|c|c|c|c|c|}
\hline \multirow{2}{*}{ Age } & \multirow{2}{*}{$\begin{array}{l}\text { No. of } \\
\text { patients }\end{array}$} & \multicolumn{6}{|c|}{ Class interval of phenylalanine conc., $\mu \mathrm{N} / \mathrm{ml}$} \\
\hline & & $<0.4$ & $0.4-0.9$ & $0.9-1.5$ & $1.5-2.1$ & $2.1-2.7$ & $>2.7$ \\
\hline $\begin{array}{l}3 \text { Months } \\
\text { Range }\end{array}$ & 28 & $\begin{array}{c}0.7 \pm 0.71(26)^{2} \\
(0-2.3)\end{array}$ & $\begin{array}{c}1.5 \pm 1.2(19) \\
(0-4.7)\end{array}$ & $\begin{array}{c}2.5 \pm 1.3(12) \\
(0.5-4.3)\end{array}$ & $\begin{array}{c}11.0 \pm 3.8(7) \\
(7.8-18.3)\end{array}$ & $\begin{array}{c}13.9 \pm 19.9(5) \\
(2.7-49.3)\end{array}$ & $\begin{array}{c}21.8 \pm 12.8(7) \\
(6.2-41.0)\end{array}$ \\
\hline $\begin{array}{l}6 \text { Months } \\
\text { Range }\end{array}$ & 11 & $\begin{array}{c}1.2 \pm 0.6(5) \\
(0.6-1.7)\end{array}$ & $\begin{array}{c}2.8 \pm 2.1(8) \\
(1.2-6.4)\end{array}$ & $\begin{array}{c}7.7 \pm 3.6(8) \\
(3.0-13.6)\end{array}$ & $\begin{array}{c}16.1 \pm 15.9(5) \\
(5.6-44.1)\end{array}$ & $\begin{array}{c}29.0 \pm 18.7(5) \\
(5.3-53.3)\end{array}$ & $\begin{array}{c}29.9 \pm 7.7(2) \\
(24.5-35.3)\end{array}$ \\
\hline $\begin{array}{l}1 \text { Year } \\
\text { Range }\end{array}$ & 9 & $\begin{array}{c}2.7 \pm 1.5(8) \\
(0.8-4.8)\end{array}$ & $\begin{array}{c}8.7 \pm 7.8(8) \\
(2.3-14.2)\end{array}$ & $\begin{array}{c}24.4 \pm 8.0(6) \\
(12.7-32.4)\end{array}$ & $\begin{array}{c}75.0 \pm 48.5(7) \\
(29.4-153.4)\end{array}$ & & \\
\hline $\begin{array}{l}2 \text { Years } \\
\text { Range }\end{array}$ & 9 & $\begin{array}{c}3.5 \pm 3.4(2) \\
(1.1-5.9)\end{array}$ & $\begin{array}{c}27.9 \pm 22.1 \\
(3.1-57)\end{array}$ & $\begin{array}{c}191.6 \pm 158.9 \\
(14.7-493)\end{array}$ & $\begin{array}{c}122.1 \pm 84.7(2) \\
(62.2-182)\end{array}$ & & \\
\hline
\end{tabular}

1 Mean $\pm \mathrm{sD}$

2 Number of observations.

Table III. o-Hydroxyphenylacetic acid in nanomolar concentration per minute as function of type of hyperphenylalaninemia and of level of phenylalanine in blood after intravenous perfusion in 6-month-old and 1-year-old children

\begin{tabular}{|c|c|c|c|c|c|c|c|}
\hline \multirow{2}{*}{ Group } & \multirow{2}{*}{$\begin{array}{c}\text { No. of } \\
\text { patients }\end{array}$} & \multicolumn{6}{|c|}{ Class interval of phenylalanine conc., $\mu \mathrm{M} / \mathrm{ml}$} \\
\hline & & $<0.4$ & $0.4-0.9$ & $0.9-1.5$ & $1.5-2.1$ & $2.1-2.7$ & $>2.7$ \\
\hline $\begin{array}{l}\mathrm{PKU}^{1} \\
\text { Range }\end{array}$ & 4 & $1.3(1)^{2}$ & $\begin{array}{c}1.5 \pm 1.1^{3}(5) \\
(0.7-3.1)\end{array}$ & $\begin{array}{c}5.8 \pm 4.8(5) \\
(2.0-13.2)\end{array}$ & $\begin{array}{c}15.0 \pm 11.1 \\
(4.2-37.0)\end{array}$ & $\begin{array}{c}22.5 \pm 8.8(3) \\
(13.7-31.4)\end{array}$ & $\begin{array}{c}27.4 \pm 5.3(4) \\
(20.2-32.8)\end{array}$ \\
\hline $\begin{array}{l}\text { Mild type } \\
\text { Range }\end{array}$ & 2 & $\begin{array}{c}1.1 \pm 0.8 \text { (3) } \\
(0.6-2.0)\end{array}$ & $3.9(1)$ & $4.5(1)$ & $\begin{array}{c}10.0 \pm 1.9(2) \\
(8.7-11.3)\end{array}$ & $\begin{array}{c}46.6 \pm 6.4(2) \\
(42.0-51.1)\end{array}$ & $72.8(1)$ \\
\hline
\end{tabular}

1 Typical and atypical PKU pooled.

2 Number of observations.

${ }^{3}$ Mean \pm sD.

Table IV. o-Hydroxyphenylacetic acid in nanomolar concentration per minute as function of type of hyperphenylalaninemia and of level of phenylalanine in blood after intravenous perfusion in children aged 2 years and more

\begin{tabular}{|c|c|c|c|c|c|c|c|}
\hline \multirow{2}{*}{ Group } & \multirow{2}{*}{$\begin{array}{l}\text { No. of } \\
\text { patients }\end{array}$} & \multicolumn{6}{|c|}{ Class interval of phenylalanine conc., $\mu \mathrm{s} / \mathrm{ml}$} \\
\hline & & $<0.4$ & $0.4-0.9$ & $0.9-1.5$ & $1.5-2.1$ & $2.1-2.7$ & $>2.7$ \\
\hline $\begin{array}{l}\text { PKUi } \\
\text { Range }\end{array}$ & 6 & & $\begin{array}{c}8.2 \pm 6.5^{2}(6)^{3} \\
(1.1-18.4)\end{array}$ & $\begin{array}{c}27.0 \pm 25.5(12) \\
(5.0-88.2)\end{array}$ & $\begin{array}{c}47.7 \pm 29.0(7) \\
(16.2-103.7)\end{array}$ & $\begin{array}{c}66.5 \pm 33.3(4) \\
(21.0-95.2)\end{array}$ & $\begin{array}{c}58.9 \pm 47.4(2) \\
(25.3-92.4)\end{array}$ \\
\hline $\begin{array}{l}\text { Mild type } \\
\text { Range }\end{array}$ & 4 & $2.0(2)$ & $\begin{array}{c}7.3 \pm 6.2(2) \\
(2.9-11.6)\end{array}$ & $\begin{array}{c}41.4 \pm 21.8(3) \\
(22.4-65.2)\end{array}$ & $\begin{array}{l}64.1 \pm 17.7(3) \\
\quad(43.7-75.6)\end{array}$ & $\begin{array}{c}162.4 \pm 23.7(2) \\
(146-179)\end{array}$ & \\
\hline
\end{tabular}

1 Typical and atypical PKU pooled.

2 Mean $\neq \mathrm{SD}$

3 Number of observations. 
age, 2, 10, and 40 times higher at 6 months, 1 year, and 2 years, respectively, than before 2 months of age; (4) that the excretion thresholds of $0.4-0.5 \mu \mathrm{mol} / \mathrm{ml}$ (7 to $8 \mathrm{mg}$ ) for 0 -OH-PAA $[3,9,11]$ and of $0.6-0.9 \mu \mathrm{mol} / \mathrm{ml}$ (10-15 $\mathrm{mg} / 100 \mathrm{ml})$ for PPA $[6,9]$ are reached only after the age of 2 years. This explains why, at the first examination, the patients with phenylalaninemia beIow $1.5 \mu \mathrm{mol} / \mathrm{ml}$ can be considered as affected by a transamination defect and why those presenting higher plasma levels and excreting enough PPA to show a positive ferric chloride test are considered immediately to be deficient in phenylalanine hydroxylase.

The fact that both PPA and o-OH-PAA excretions are reduced suggests strongly a delayed maturation of phenylalanine transaminase, even in the absence of its direct assay in crude liver homogenates; such an assay would, furthermore, be difficult to interpret because tyrosine- $\alpha$-ketoglutarate transaminase, already active at birth $[19,20]$, also has some affinity for phenylalanine [17]. This probable delayed maturation could account in part, with the relative reduction in protein intake [21], for the decrease of phenylalaninemia as children grow older.

Finally, perfusion data show that no significant distinction can be made later in PPA and o-OH-PAA excretions between PKU and mild forms, insofar as phenylalaninemia is raised to a sufficiently high level. This definitely eliminates, in cases studied by this technique, the hypothesis of a permanent transamination defect, although the possibility of such a mutation cannot be ruled out in other cases.

\section{Summary}

Quantitative studies of excretion of 0 -OH-PAA in urine show that it is dependent on both the age of the child (under 2 years of age) and the level of phenylalanine in plasma. In this regard, no distinction can be made between PKU and its genetic variants.

\section{References and Notes}

1. Allen, R. J., Heffelfinger, J. C., Masotti, R. E., and TSAU, M. U.: Phenylalanine hydroxylase activity in newborn infants. Pediatrics, 33: 512 (1964).

2. Allen, R. J., AND WILson, J. L.: Urinary phenylpyruvic acid in phenylketonuria. J. Amer. Med. Ass., 188: 720 (1964).

3. Armstrong, M. D., Shaw, K. N. F., and Robinson, K. S.: Studies on phenylketonuria. II. The excretion of $o$-hydroxyphenylacetic in phenylketonuria. J. Biol. Chem., 213: 797 (1955).

4. Armstrong, M. D., and Binkley, E. L., Jr.: Studies on phenylketonuria. V. Observations on a newborn infant with phenylketonuria. Proc. Soc. Exp. Biol. Med., 93: 418 (1956).

5. Armstrong, M. D., Shaw, K. N. F., and Wall, P. E.: The phenolic acids of human urine: Paper chromatography of phenolic acids. J. Biol. Chem., 218: 293 (1956).

6. ARMstrong, M. D., AND Low, N. L.: Phenylketonuria. VIII. Relation between age, serum phenylalanine level, and phenylpyruvic acid excretion. Proc. Soc. Exp. Biol. Med., 94: 142 (1957).

7. Auerabch, V. H.: Discussion of the paper of Allen, R. J., SPIRITO, R. A., AND SHAH, R. M.: The influence of metabolic variations in the diagnosis of phenylketonuria in infancy. $\mathrm{J}$. Pediat., 67: 920 (1965).

8. Auerbach, V. H., Di George, A. M., and Carpenter, G. G.: Phenylalaninemia. A study of the diversity of disorders which produce elevation of blood concentration of phenylalanine. In: W. L. Nyhan: Amino Acid Metabolism and Genetic Variation, p. 11 (McGraw-Hill, New York, 1967).

9. Berry, H. K., Sutherland, B. S., Guest, G. M., AND UMBARger, B.: Chemical and clinical observations during treatment of children with phenylketonuria. Pediatrics, 21 : 929 (1958).

10. Clayton, B. E.: Phenylketonuria. J. Med. Genet., 8: 37 (1971).

11. Cullen, A. M. AND Knox, W. E.: o-hydroxyphenylacetic acid excretion in the phenylalanine tolerance test for carriers of phenylketonuria. Proc. Soc. Exp. Biol. Med., 99: 219 (1958)

12. Frézal, J., Rey, J., Rey, F., and Briard-Gullliemot, M. L.: Incidence et classification des hyperphénylalaninémies (Abstracts). XIII International Congress of Pediatrics, Vienna, August 29-September 4, 1971, Vol. I-98, p. 455.

13. GaLli, J.: Exploration du métabolisme de la phénylalanine. Application à l'étude de la phénylcétonurie. Thèse de Pharmacie, Paris (1969).

14. Hill, J. B., Summer, G. K., Pender, M. W., and Roszel, N. O.: An automated procedure for blood phenylalanine. Clin. Chem., 11: 541 (1965).

15. Horner, F. A., and Streamer, C. W.: Phenylketonuria treated from earliest infancy. Report of three cases. Amer. J. Dis. Child., 97: 345 (1959).

16. Humbel, R.: Le dosage de l'acide ortho-hydroxyphénylacétique dans l'urine et son intérêt pour le diagnostic de la phénylcétonurie. J. Pharm. Belg., 22: 243 (1967).

17. JACOBY, G. A., AND LADU, B. N.: Nonspecificity of tyrosine transaminase: An explanation for the simultaneous induction of tyrosine, phenylalanine, and tryptophan transaminase activities in rat liver. Biochem. Biophys. Res. Commun., 8: 352 (1962).

18. Knox, W. E.: Phenylketonuria. In: J. B. Stanbury, J. B. Wyngaarden, and D. S. Fredrickerson: The Metabolic Basis in Inherited Disease. Ed. 3, p. 266 (McGraw-Hill, New York, 1972).

19. Kretchmer, N., Levine, S. Z., McNamara, H., and BarNETT, H. L.: Certain aspects of tryosine metabolism in the young. I. The development of the tyrosine oxidizing system in human liver. J. Clin. Invest., 35: 236 (1956).

20. Kretchmer, N.: Development biochemistry: A relevant endeavor. Pediatrics, 46: 175 (1970).

21. Partington, M. W., And Lewis, E. J. M.: Variations with 
age in plasma phenylalanine and tyrosine levels in phenylketonuria. J. Pediat., 62: 348 (1963).

22. REY, F., AND REY, J.: Classification des hyperphénylalaninémies. In: Journées parisiennes de Pédiatrie, p. 329 (Flammarion, Paris, 1969).

23. Rey, F., Sivy, M., AND Rey, J.: Séparation rapide des acides aminés aromatiques et ramifiés par chromatographie sur colonne échangeuse d'ions: Application à la surveillance des leucinoses et des hyperphénylalaninémies. Rev. Eur. Etudes Clin. Biol., 17: 221 (1972).

24. Technicon AutoAnalyzer, Technicon Corporation, Domont, France.
25. We are indebted to the dietitian and the nurses who provided diligent and devoted care to the patients while they were hospitalized in the metabolic unit.

26. This work was presented in part at the XIII International Congress of Pediatrics, Vienna, September 1971 [12].

27. This work was supported by research grants from the Institut National de la Santé et de la Recherche Médicale.

28. Requests for reprints should be addressed to: F. REY, Unité de Recherches de Génétique Médicale, Hôpital des Enfants-Malades, 149 Rue de Sèvres, 75730 Paris Cedex 15, France.

29. Accepted for publication December 26, 1973. 